$12-1980$

\title{
Urban Policy: Does Political Structure Matter?
}

David R. Morgan

University of Oklahoma

John P. Pelissero

Loyola University Chicago, jpeliss@luc.edu

Follow this and additional works at: https://ecommons.luc.edu/politicalscience_facpubs

Part of the Political Science Commons

\section{Recommended Citation}

Morgan, David R. and John P. Pelissero, "Urban Policy: Does Political Structure Matter?", The American Political Science Review 74 (December 1980): 999-1006.

This Article is brought to you for free and open access by the Faculty Publications and Other Works by Department at Loyola eCommons. It has been accepted for inclusion in Political Science: Faculty Publications and Other Works by an authorized administrator of Loyola eCommons. For more information, please contact ecommons@luc.edu. (c) (1) $(9)$

This work is licensed under a Creative Commons Attribution-Noncommercial-No Derivative Works 3.0 License. 


\title{
- Urban Policy: Does Political Structure Matter?
}

\author{
DAVID R. MORGAN \\ JOHN P. PELISSERO \\ University of Oklahoma
}

\begin{abstract}
An interrupted time-series quasi-experiment is employed to test the basic hypothesis that reformed cities (with city manager, at-large elections, and nonpartisan ballots) tax and spend less than unreformed communities. Eleven cities with populations of 25,000 and above which significantly changed their political structure between 1948 and 1973 are compared with 11 matched control cities that made no changes. We found that over an 11 -year period, variations in fiscal behavior were virtually unaffected by changes in city government structure.
\end{abstract}

Among scholars of state and local government, the question is still debated: do politics and governmental structure have any independent influence on policies? Although much state-level research suggests the answer is clearly yes, considerably less agreement exists for the local level. Most research directed toward this issue at the urban level has probed the political effects of reformed institutions. Presumably urban reformers, who sought to replace the political machine with good government devices, sought certain policy goals as well. Just what those goals were and how successful these groups have been in acheiving them remains unsettled. Some argue that one of the consequences of the reform movement's "public-regarding" ethos was to provide greater support for spending on community-wide public improvements. Others disagree. They contend that cities with reform institutions tend to be less responsive to their socioeconomic environments, which presumably causes such municipalities to be less sensitive to the higher spending demands of lower-income and minority interests. The result, according to the latter argument-lower levels of taxing and spending. Thus the issue for local government remains unsettled.

The argument over the political consequences of urban reform has been clouded by several methodological disputes. One of the most important relates to time order. For example, Lineberry AND Fowler (1967, p. 707) insist that one wellknown analysis of the reform movement's effect on city government structure (Wolfinger and

We would like to acknowledge Richard Bingham, University of Wisconsin, Milwaukee, for suggesting the need for a study of this sort. Robert England deserves special thanks for his valuable assistance in managing and processing the data. Bruce Kennedy helped with the data gathering and coding as well. Finally, we are greatly indebted to Kenneth J. Meier, University of Oklahoma, whose methodological help has been invaluable.
Field, 1966) is flawed in a causal sense because obvious time order assumptions are violated; independent variables (census data) are used to explain decisions (government structure) made at an earlier period. Yet none of the research on this topic systematically includes a time element; it has all been cross-sectional in design. The research reported here offers a different approach-a timeseries analysis-in an effort to shed further light on this basic question.

\section{Public Policy Implications of Municipal Reform}

One of the most pervasive themes concerning the effect of municipal reforms derives from the public-regarding thesis first proffered by Banfield and Wilson (1963; p. 46). According to these authors, certain subcultural groups within the city, constituted on ethnic and income lines, sought a more rational, efficient, and honest city government. These groups presumably based their political preferences on some conception of the public interest as a whole in contrast to a more narrow ward or neighborhood orientation. As a principal means of promoting these goals, such public-regarding groups pushed the "good government" agenda of municipal reforms. Such institutional arrangements as council-manager government, nonpartisan ballots, and at-large elections seem entirely consistent with the commitment of these groups to minimizing partisanship and particularism in favor of the universal values of the larger community.

The public-regarding ethos had other political results as well. A concern for the larger whole, according to Banfield and Wilson, might lead to support for various community-wide projects and improvements. Indeed, Wilson and Banfield (1964) show that certain putatively publicregarding groups tended to vote against their selfinterest, narrowly conceived, in favor of expenditure proposals that would raise their taxes. Others (Boskoff and Zeigler, 1964, pp. 46-47; 
Uyekt, 1966) find a similar association between upper-status groups and support for bond elections for municipal improvements. Thus the causal sequence is complete-an upper-middle class public-regarding ethic should yield two results-municipal reforms and greater expenditures for public improvements.

This line of reasoning has not been so obvious to many. In fact, the whole public-regarding ethos has been rather severely challenged. Hennessey (1970) avers that the approach is not a genuine theory and, further, that it was tested with aggregate voting statistics although it was clearly applicable only to individual voting behavior. Others have failed to find evidence to sustain the ethos hypothesis (Wolfinger and Field, 1966; Bowman, Ippolito, and Levin, 1972; Duran, 1972). Miller and Bennett (1974) even insist that a subsequent effort at revisiting the ethos formulation by Wilson and Banfield (1971) contains a serious methodological flaw that disproves the whole concept.

Despite the problems associated with the ethos notion, the most widely referenced study on the effects of reforms on city fiscal behavior begins with that premise. Lineberry and Fowler (1967) argue that reformers were especially hostile to the political machine's attempt to capitalize on community cleavages-class, ethnic, racial, or religious. Reforms were presumably desired as a way of insulating municipal governments from such divisive social forces. One of their basic purposes was to determine if indeed reform governments responded differently from nonreformed governments to their socioeconomic environment. Their analysis of tax and expenditure burdens in cities of 50,000 and over confirms this expectation. Socioeconomic variables were much more closely associated with taxing and spending in unreformed than in reformed cities. ${ }^{1}$ But what about tax and expenditure levels? Contrary to the public-regarding view, reform cities had lower tax and expenditure burdens. They infer from this finding that reformed institutions indeed do maximize the power of the middle class, but that

'In fact, Wright (1976) has challenged Lineberry and Fowler's conclusion, arguing that their research is flawed because correlation coefficients are used in comparing groups of cities. He insists the proper comparison is between unstandardized regression coefficients. When Wright further tests the Lineberry and Fowler thesis using a multiple regression model in which the slope of each SES variable is allowed to vary within each category of reform, he finds no support for their position. "None of the SES variables becomes systematically less strongly related to policy outputs as reformism increases"' (p. 369). group apparently wants less, not more, public spending.

This finding that reforms produce lower spending commitments is not inconsistent with another body of thought regarding the goals of municipal reformers. Hays (1964) contends that the municipal reform movement was dominated by the upper class with extensive support from business organizations. Such groups, who had little need for high-priced social programs, were primarily interested in having traditional housekeeping services economically provided. Business-oriented reformers were also eager to create a favorable climate for profit-making in the city, providing another motive for municipal efficiency (Judd, 1979, pp. 111-12). According to this reasoning, reform structures should lead to lower levels of taxing and spending, just as Lineberry and Fowler (1967) and others find (Lyons, 1978).

Finally, some contend that reforms make no real policy differences. Presumably, both structure and policy are the result of the same antecedent influences, either region (Wolfinger and Field, 1966; Cole, 1971) or the socioeconomic characteristics of the community (Hawkins, 1971, Ch. 3).

In sum, despite the provocative publicregarding thesis, most research suggests that municipal reforms should either reduce taxing or spending or have little noticeable effect. As indicated above, all these studies, regardless of their findings, have been cross-sectional in design. Or at least changes in government structure over time have not been examined for their possible effect on policy variations. No attempt has been made to assess policy changes among cities that have altered their government institutions. Surely the debate over the potential policy consequences of the local political system should not be settled solely on the basis of cross-sectional findings. We need to consider what happens to certain municipal policies over a period of time when a city changes its basic political structure.

\section{Research Design}

We employ a quasi-experimental time-series design (Campbell and Stanley, 1966; pp. 55-57) to test the policy effects of municipal reform. Two groups of cities are required, one in which a change takes place and a comparable group not undergoing the experimental change from which similar "control" time-series data can be gathered. The design not only controls for virtually all the customarily identified threats to internal validity, but also it readily lends itself to public policy applications (see Meier, forthcoming).

In this analysis, government structure 
represented by the elements of reform (city manager, at-large representation, nonpartisan elections) serves as the independent variable. Among cities with populations of 25,000 and above, eight cities were found that changed a completely unreformed structure to a totally reformed government during a single year between 1948 and 1973. Another three cities were found that began with all of the reform elements and dropped at least two of these in a single year. ${ }^{2}$ Apparently only one city, since 1950 , has dropped all three reform elements in a single year. A second group of eleven cities, which began with the same form of government and maintained this structure, were matched to specific cities in the first group. Cities that experienced a change in government structure constitute the "experimental" group and those cities that did not become the "control" or "match" group. Table 1 includes both groups of cities, the year of structural change for the experimental cities, and the structural components.

A brief comment should be made regarding the matching procedure. The following criteria were employed to select the matching cities: (1) a comparable form of government with the experimental city before the change; (2) similar economic base; (3) a similarity in one of the dependent variables, per capita general revenue. Matching by both economic base and per capita general revenue should minimize the possibility that observed changes in fiscal behavior over time might result from differing socioeconomic characteristics between the pairs of cities. One additional important characteristic of our cities should be noted-functional responsibility. Differences in spending assignments among cities must be considered when expenditures are analyzed. This is particularly true for schools and welfare, since these two very expensive activities can account for about half the variation in total general municipal expenditures (Liebert, 1974, pp. 771-72). Our experimental and control cities are perfectly congruent on school and welfare responsibilities.

The time-series analysis includes an examination of 7 revenue and expenditure variables over an 11-year period-the year of change and 5 years before and after that intervention. The dependent variables consist of per capita measures of (1) general revenue, (2) general expenditures, (3) police expenditures, (4) fire expenditures, (5)

\footnotetext{
${ }^{2}$ Although the decision to treat municipal reforms as additive is debatable (see Lyons, 1977), Bryant (1976) has shown that the three customarily used items (with commission form considered as a reform structure) do meet the .90 criterion for a Guttman scale using all cities having populations of 25,000 and over.
}

highway expenditures, (6) sanitation expenditures, and (7) parks and recreation expenditures. ${ }^{3}$ We would prefer to have additional measures that could be used to assess differences in spending for social programs, but our fiscal measures represent all such data of any consequence consistently available from the Census Bureau over the past several decades.

\section{Findings}

Although results of an interrupted time-series design are often displayed graphically, visual examination may be inconslusive. Thus it is necessary to test for the effects of the intervention statistically. McCain and McCleary (1979) offer a method for performing an ordinary regression that estimates the parameters for the initial level of spending, the slope (spending trend over time), change in level, and change in slope (both potentially resulting from the intervention). These potential effects can be represented with the following regression equation:

$$
\hat{Y}_{t}=a_{1}+b_{1} X_{1 t}+b_{2} X_{2 t}+b_{3} X_{3 t}+e_{t}
$$

In this equation the independent variable $X_{1 t}$ is a linear measure of time such that $X_{17}$ equals 1,2 , $3, \ldots, N$. The parameter $b_{1}$ is the slope of the series. $X_{2 t}$ is a dummy variable where $X_{2 t}=0$ before the reform change and $X_{2 t}=1$ after the intervention. The parameter $b_{2}$ thus represents the alteration in level (intercept) following reform change. Variable $X_{3 t}$ is also a dummy "countervariable" where $X_{3 t}=0$ before the intervention and $X_{3 t}=X_{1 t}$ after the intervention (i.e., 1, 2, 3 ...). The parameter $b_{3}$ represents the post-intervention change in slope. If the parameters $b_{2}$ and $b_{3}$ are not statistically significant, ${ }^{4}$ we may accept

${ }^{3}$ Data sources for these variables include U.S. Bureau of the Census, City Government Finances (1945-1978); International City Management Association, Municipal Year Book (1945-1978); and the Rand McNally Commercial Atlas and Marketing Guide (1945-1978), which provided estimates of city populations for use in calculating the per capita measures for non-census periods. Capital outlays have been removed from all expenditures where the data permit, i.e., general expenditures and highways (capital expenditures could not be excluded, however, for any of the 1940s data). Where the breakdown was available (since 1960), sanitation expenditures do not include sewerage.

4Although tests of statistical significance are not strictly applicable to data representing a total population, such tests are commonly employed as a way of depicting "sizable" relationships. Because of the small number of time points in the analysis and the need to emphasize changes that are more than minimal, only those changes in the intercept and slope that reach the .01 level of significance are reported. 
the null hypothesis that reform interventions produced no effect. In the opposite case, if these two parameters are significant, we must then look for autocorrelation before we may assume that reforms made a difference. Note that the formula to be used consists of only the three time-related variables; no measures of the social and economic characteristics of the cities are included. Omission of the usual socioeconomic variables appears justified for three reasons. Assuming the match is well done, the pairs of cities should be similar in certain fundamental ways. Second, as the subsequent analysis will reveal, the level of explained variance for almost all the equations is so high that any additional independent variables would add virtually no explanation. Finally, with an $N$

Table 1. Experimental and Control Cities, Government Structure and Economic Base $(N=22)$

\begin{tabular}{|c|c|c|c|c|c|}
\hline \multirow[b]{2}{*}{ A. Experimental } & \multirow{2}{*}{$\begin{array}{l}\text { Year of } \\
\text { Change }^{a}\end{array}$} & \multirow{2}{*}{$\begin{array}{c}\text { Economic } \\
\text { Base }^{b}\end{array}$} & \multicolumn{2}{|c|}{ Government Structure } & \multirow{2}{*}{$\begin{array}{c}\text { Net } \\
\text { Change }\end{array}$} \\
\hline & & & Before Change & After Change & \\
\hline $\begin{array}{l}\text { 1. Council Bluffs, Iowa } \\
\text { 2. Peoria, Illinois } \\
\text { 3. Rock Island, Illinois } \\
\text { 4. Brockton, Massachusetts } \\
\text { 5. Huntington, West Virginia } \\
\text { 6. Little Rock, Arkansas } \\
\text { 7. Independence, Missouri } \\
\text { 8. Great Falls, Montana } \\
\text { 9. Worcester, Massachusetts } \\
\text { 10. Kenosha, Wisconsin } \\
\text { 11. Brockton, Massachusetts }\end{array}$ & $\begin{array}{l}1951 \\
1954 \\
1954 \\
1958 \\
1958 \\
1958 \\
1962 \\
1973 \\
1950 \\
1958 \\
1962\end{array}$ & $\begin{array}{l}\mathrm{T} \\
\mathrm{Mr} \\
\mathrm{Mm} \\
\mathrm{Mm} \\
\mathrm{Mr} \\
\mathrm{Rm} \\
\mathrm{Rm} \\
\mathrm{Rr} \\
\mathrm{Mm} \\
\mathrm{Mm} \\
\mathrm{Mm}\end{array}$ & $\begin{array}{l}M C-M-P \\
M C-W-P \\
M C-W-P \\
M C-M-P \\
M C-M-P \\
M C-W-P \\
M C-W-P \\
M C-W-P \\
C M-A-N P \\
C M-A-N P \\
C M-A-N P\end{array}$ & $\begin{array}{l}\mathrm{CM}-\mathrm{A}-\mathrm{NP} \\
\mathrm{CM}-\mathrm{A}-\mathrm{NP} \\
\mathrm{CM}-\mathrm{A}-\mathrm{NP} \\
\mathrm{CM}-\mathrm{A}-\mathrm{NP} \\
\mathrm{CM}-\mathrm{A}-\mathrm{NP} \\
\mathrm{CM}-\mathrm{A}-\mathrm{NP} \\
\mathrm{CM}-\mathrm{M}-\mathrm{NP} \\
\mathrm{CM}-\mathrm{A}-\mathrm{NP} \\
\mathrm{MC}-\mathrm{W}-\mathrm{P} \\
\mathrm{MC}-\mathrm{W}-\mathrm{NP} \\
\mathrm{MC}-\mathrm{M}-\mathrm{NP}\end{array}$ & $\begin{array}{l}+3 \\
+3 \\
+3 \\
+3 \\
+3 \\
+3 \\
+3 \\
+3 \\
-3 \\
-2 \\
-2\end{array}$ \\
\hline B. Control & $\begin{array}{c}\text { Economic } \\
\text { Baseb }^{-}\end{array}$ & & & & \\
\hline $\begin{array}{l}\text { 1. Davenport, Iowa } \\
\text { 2. Terre Haute, Indiana } \\
\text { 3. Muncie, Indiana } \\
\text { 4. Cranston, Rhode Island } \\
\text { 5. Hammond, Indiana } \\
\text { 6. Charleston, West Virginia } \\
\text { 7. Berwyn, Ilinois } \\
\text { 8. Billings, Montana } \\
\text { 9. Hartford, Connecticut } \\
\text { 10. Clifton, New Jersey } \\
\text { 11. Lowell, Massachusetts }\end{array}$ & $\begin{array}{l}\mathrm{Rm} \\
\mathrm{Mr} \\
\mathrm{Mm} \\
\mathrm{Mm} \\
\mathrm{M} \\
\mathrm{Rr} \\
\mathrm{Rr} \\
\mathrm{Rr} \\
\mathrm{M} \\
\mathrm{Mm} \\
\mathrm{Mm}\end{array}$ & $\begin{array}{l}\mathrm{MC}- \\
\mathrm{MC}- \\
\mathrm{MC}- \\
\mathrm{MC}- \\
\mathrm{MC}- \\
\mathrm{MC}- \\
\mathrm{MC}- \\
\mathrm{MC}- \\
\mathrm{CM}- \\
\mathrm{CM}- \\
\mathrm{CM}-\end{array}$ & $\begin{array}{l}-P \\
-P \\
-P \\
-P \\
-P \\
-P \\
-P \\
-N P \\
-N P \\
-N P\end{array}$ & & \\
\hline
\end{tabular}

Source: International City Management Association, Municipal Year Book (1945-1978), Washington, D.C.

${ }^{a}$ First year city altered government structure.

${ }^{\mathrm{b}}$ Cities classified according to employment patterns, as follows:

$\mathbf{T}=$ Transportation center (25 percent or more reported transportation as occupation)

$\mathrm{Mm}=$ Manufacturing city (50 percent employed in manufacturing)

$\mathrm{Mr}=$ Diversified city (employment in manufacturing dominant but less than 50 percent)

Rr = Retail trade city (retail employment is greater than that in wholesale trade, service, or manufacturing)

$\mathrm{Rm}=$ Diversified city (retail employment dominant, manufacturing employment at least 20 percent)

cForm of government, representation, and ballot type, as follows:

$\mathrm{CM}=$ City manager form

MC = Mayor-council form

$A=$ At-large representation

$\mathrm{W}=$ Representation by ward or district

NP = Nonpartisan ballot

$\mathbf{P}=$ Partisan ballot

${ }^{d}$ Number of reform elements present after change.

e Constant structural arrangements during the period analyzed. 
of 11 (time points), adding more explanatory variables runs the risk of overdetermining the equation and exhausting the needed degrees of freedom.

Here we should note that the dependent variables in the analysis to follow are mean figures for cities grouped into four categories-more reformed experimental cities $(N=8)$, less reformed experimental cities $(N=3)$, and the two groups of control cities. This averaging process permits us to report far fewer equations and has the additional advantage of smoothing out any potential abrupt changes in spending peculiar to a given municipality. ${ }^{5}$ Nonetheless, as an additional precaution, a separate time-series analysis was undertaken for each individual city, the results of which are summarized below.

The results of the initial analysis are found in Table 2. The regression coefficients are shown for each variable along with the degree of statistical significance for each and the level of explained variance $\left(R^{2}\right)$ for the equation. Our first concern is to determine how many statistically significant relationships exist for variables 2 (intercept) and 3 (slope). In fact, few significant differences are found for the two variables. For the total of 28 equations only 9 reflect statistical significance at the .01 level for either variable 2 or 3 . More than this only 4 of these 9 equations show statistical significance for those cities undergoing structural change. Otherwise all significant changes are for control cities. As with any time series, our results must also be tested for autocorrelation. If serial correlation is present, the differences between the pre-intervention and post-intervention period is likely to be overstated (Ostrom, 1978, p. 29). We might thus conclude in our case that reforms made a difference when in fact they did not. Our test is made using a procedure developed by Pack (1977), which is actually the first step in the BoxJenkins (1970) method for identifying autocorrelation. If the $Q$ statistic produced by the test, shown in Table 2, is not significant (using a chisquare distribution), no autocorrelation exists. ${ }^{6}$

\footnotetext{
sith a small number of cases, especially with the possibility of considerable variation on certain variables, one might consider standardizing the variables before averaging. For each city, the per capita measure for every year was converted to a Z-score for each of the 7 functional categories. These standardized values were then used in the time-series analysis described in the text. Only a few changes resulted, which appeared to be so minor that we felt justified in omitting the standardization procedure and have reported the data on a per capita basis to make interpretation easier.

'We are greatly indebted to Ken Meier for making available the computer program necessary to generate the $Q$ statistic.
}

Using the less demanding .05 level, only one of the nine significant intercepts and slopes reflects autocorrelation. Since the autocorrelation is for a control group, we may safely ignore it; it will not affect our basic hypothesis concerning the impact of reform structures.

One more basic issue must be addressed at this point. Four equations involving experimental cities did contain significant changes apparently resulting from the intervention. But what about the direction of change? If the change in spending is not in the right direction, reform does not produce the expected impact. The results of these four equations showing the direction of change for the intercept or slope is as follows (positive direction means spending increased; negative direction, the opposite): (1) general expenditures for less reformed cities have a positive slope change; (2) police spending in more reformed cities shows a positive intercept change; (3) sanitation spending for more reformed communities manifests a positive intercept change; and (4) highway expenditures in less reformed municipalities reflect a positive slope change.

All the changes are positive, indicating more than expected increases in spending following structural change. But note that two of the equations-police and sanitation spending-are for groups of cities that became more reformed. Those cities, in line with the presumed effect of reforms, should have spent less after the structural change took place. So, in all, for 28 tests of the effects of reform, only two structural changes (7 percent) produce the expected modifications in revenue and spending levels. Moreover, just as many significant effects of structural change among experimental cities are in the wrong direction. These findings clearly do not bode well for the theoretical assumptions growing out of the reform literature.

The relationship between municipal reforms and policy changes were tested in three other ways. First, a time-series analysis was performed for each city separately (without averaging). Of the 39 significant changes (in intercept or slope) of a total 156 possible, 16 occurred among experimental cities. But exactly half of these changes were in the wrong direction. Second, each experimental city was compared directly with its control counterpart for each of the 7 policies. Of the 11 cases where an experimental city reflected a change that was not found in its control, 6 were in the wrong direction. Finally, changes in spending patterns among the functional areas were examined by calculating the percentage of general expenditures devoted to each of four spending categories. These data were then employed as dependent variables in a similar time-series analysis. In only two equations did statistically significant var- 
Table 2. Regression Coefficients for OLS Equation for All Sets of Cities to Test for Significance of Change in Reform Structure (Betas in Parentheses)

\begin{tabular}{|c|c|c|c|c|c|c|c|c|}
\hline \multirow[b]{2}{*}{$\begin{array}{l}\text { Dependent Variable } \\
\text { (per capita) }\end{array}$} & \multicolumn{8}{|c|}{ Independent Variables } \\
\hline & Time & $\begin{array}{c}F: \\
\text { Value }\end{array}$ & $\begin{array}{c}\text { Intervention } \\
\text { Intercept }\end{array}$ & $\begin{array}{c}F- \\
\text { Value }\end{array}$ & $\begin{array}{c}\text { Intervention } \\
\text { Slope }\end{array}$ & $\begin{array}{c}F \\
\text { Value }\end{array}$ & $\mathbf{R}^{2}$ & $\begin{array}{c}\text { Pack's } \\
Q^{*}\end{array}$ \\
\hline \multicolumn{9}{|l|}{ General Revenue } \\
\hline More Reform $(\mathbb{N}=8)$ & $\begin{array}{l}4.09 \\
(.86)\end{array}$ & $<.01$ & $\begin{array}{l}4.28 \\
(.14)\end{array}$ & ns & $\begin{array}{l}.00 \\
(.00)\end{array}$ & ns & .98 & \\
\hline Control $(\mathrm{N}=8)$ & $\begin{array}{c}3.95 \\
(1.00)\end{array}$ & $<.01$ & $\begin{array}{c}5.32 \\
(.21)\end{array}$ & $<.01$ & $\begin{array}{l}-1.60 \\
(-.23)\end{array}$ & ns & .99 & 4.34 \\
\hline Less Reform $(\mathrm{N}=3)$ & $\begin{array}{c}6.37 \\
(1.09)\end{array}$ & $<.01$ & $\begin{array}{l}-1.40 \\
(-.04)\end{array}$ & ns & $\begin{array}{l}-.84 \\
(-.08)\end{array}$ & ns & .98 & \\
\hline Control $(\mathrm{N}=3)$ & $\begin{array}{l}8.85 \\
(1.30)\end{array}$ & $<.01$ & $\begin{array}{l}-8.37 \\
(-.19)\end{array}$ & ns & $\begin{array}{l}-2.07 \\
(-.17)\end{array}$ & ns & .98 & \\
\hline \multicolumn{9}{|l|}{ General Expenditures } \\
\hline More Reform & $\begin{array}{l}4.00 \\
(.82)\end{array}$ & $<.01$ & $\begin{array}{l}6.46 \\
(.21)\end{array}$ & ns & $\begin{array}{l}-.22 \\
(-.03)\end{array}$ & ns & .97 & \\
\hline Control & $\begin{array}{l}3.54 \\
(.82)\end{array}$ & $<.01$ & $\begin{array}{l}10.20 \\
(.37)\end{array}$ & $<.01$ & $\begin{array}{l}-1.48 \\
(-.19)\end{array}$ & ns & .99 & $8.84 * *$ \\
\hline Less Reform & $\begin{array}{l}6.10 \\
(.76)\end{array}$ & $<.01$ & $\begin{array}{l}-9.37 \\
(-.18)\end{array}$ & ns & $\begin{array}{c}6.08 \\
(.42)\end{array}$ & $<.01$ & .99 & 4.51 \\
\hline Control & $\begin{array}{l}10.41 \\
(1.05)\end{array}$ & $<.01$ & $\begin{array}{l}1.86 \\
(.03)\end{array}$ & ns & $\begin{array}{l}-1.76 \\
(-.10)\end{array}$ & ns & .98 & \\
\hline \multicolumn{9}{|l|}{ Police Expenditures } \\
\hline More Reform & $\begin{array}{l}.41 \\
(.64)\end{array}$ & $<.01$ & $\begin{array}{l}1.10 \\
(.27)\end{array}$ & $<.01$ & $\begin{array}{l}.13 \\
(.12)\end{array}$ & ns & .99 & 2.58 \\
\hline Control & $\begin{array}{l}.50 \\
(.86)\end{array}$ & $<.01$ & $\begin{array}{c}.53 \\
(.14)\end{array}$ & $<.01$ & $\begin{array}{l}.01 \\
(.01)\end{array}$ & ns & .99 & 3.48 \\
\hline Less Reform & $\begin{array}{l}.36 \\
(.79)\end{array}$ & $<.01$ & $\begin{array}{l}-.58 \\
(-.20)\end{array}$ & ns & $\begin{array}{l}.32 \\
(.39)\end{array}$ & ns & .97 & \\
\hline Control & $\begin{array}{l}.79 \\
(.98)\end{array}$ & $<.01$ & $\begin{array}{l}-.87 \\
(-.17)\end{array}$ & ns & $\begin{array}{l}.24 \\
(.17)\end{array}$ & ns & .98 & \\
\hline \multicolumn{9}{|l|}{ Fire Expenditures } \\
\hline More Reform & $\begin{array}{c}.62 \\
(1.34)\end{array}$ & $<.01$ & $\begin{array}{l}-.11 \\
(-.04)\end{array}$ & ns & $\begin{array}{l}-.35 \\
(-.42)\end{array}$ & ns & .91 & \\
\hline Control & $\begin{array}{r}.48 \\
(.75)\end{array}$ & $<.01$ & $\begin{array}{c}2.01 \\
(.49)\end{array}$ & $<.01$ & $\begin{array}{l}-.27 \\
(-.24)\end{array}$ & ns & .98 & 4.81 \\
\hline Less Reform & $\begin{array}{l}.36 \\
(.81)\end{array}$ & ns & $\begin{array}{l}-.43 \\
(-.15)\end{array}$ & ns & $\begin{array}{l}.22 \\
(.28)\end{array}$ & ns & .88 & \\
\hline Control & $\begin{array}{l}.90 \\
(1.12)\end{array}$ & $<.01$ & $\begin{array}{l}1.17 \\
(.24)\end{array}$ & ns & $\begin{array}{l}-.63 \\
(-.46)\end{array}$ & $<.01$ & .97 & 1.63 \\
\hline \multicolumn{9}{|l|}{ Sanitation Expenditures } \\
\hline More Reform & $\begin{array}{l}.38 \\
(.33)\end{array}$ & ns & $\begin{array}{c}7.02 \\
(.95)\end{array}$ & $<.01$ & $\begin{array}{l}-.84 \\
(-.40)\end{array}$ & ns & .84 & 3.37 \\
\hline Control & $\begin{array}{c}.72 \\
(.53)\end{array}$ & ns & $\begin{array}{l}-3.53 \\
(-.41)\end{array}$ & ns & $\begin{array}{c}1.82 \\
(.75)\end{array}$ & ns & .81 & \\
\hline Less Reform & $\begin{array}{c}.41 \\
(.54)\end{array}$ & ns & $\begin{array}{l}.21 \\
(.04)\end{array}$ & ns & $\begin{array}{l}.25 \\
(.18)\end{array}$ & ns & .55 & \\
\hline Control & 1.00 & $<.01$ & -1.89 & ns & -.36 & ns & .74 & \\
\hline Parks Expenditures & $(1.44)$ & & $(-.43)$ & & $(-.30)$ & & & \\
\hline More Reform & $\begin{array}{c}.06 \\
(.16)\end{array}$ & ns & $\begin{array}{c}.29 \\
(.11)\end{array}$ & ns & $\begin{array}{c}.49 \\
(.69)\end{array}$ & ns & .88 & \\
\hline Control & $\begin{array}{c}.43 \\
(1.36)\end{array}$ & $<.01$ & $\begin{array}{l}.74 \\
(.37)\end{array}$ & ns & $\begin{array}{c}-.57 \\
(-1.02)\end{array}$ & ns & .79 & \\
\hline Less Reform & $\begin{array}{l}.22 \\
(.84)\end{array}$ & ns & $\begin{array}{c}-.05 \\
(-.03)\end{array}$ & ns & $\begin{array}{c}.05 \\
(.11)\end{array}$ & ns & .83 & \\
\hline Control & $\begin{array}{c}.32 \\
(1.23)\end{array}$ & $<.01$ & $\begin{array}{l}-.35 \\
(-.21)\end{array}$ & ns & $\begin{array}{l}-.08 \\
(-.17)\end{array}$ & ns & .83 & \\
\hline
\end{tabular}


Table 2. (continued)

\begin{tabular}{|c|c|c|c|c|c|c|c|c|}
\hline \multirow[b]{2}{*}{$\begin{array}{l}\text { Dependent Variable } \\
\text { (per capita) }\end{array}$} & \multicolumn{8}{|c|}{ Independent Variables } \\
\hline & Time & $\begin{array}{c}F \\
\text { Value }\end{array}$ & $\begin{array}{c}\text { Intervention } \\
\text { Intercept }\end{array}$ & $\begin{array}{c}F- \\
\text { Value }\end{array}$ & $\begin{array}{l}\text { Intervention } \\
\text { Slope }\end{array}$ & $\begin{array}{c}F- \\
\text { Value }\end{array}$ & $\mathbf{R}^{2}$ & $\begin{array}{c}\text { Pack's } \\
\text { Q* }^{*}\end{array}$ \\
\hline \multicolumn{9}{|l|}{ Highway Expenditures } \\
\hline More Reform & $\begin{array}{c}.64 \\
(.98)\end{array}$ & $<.01$ & $\begin{array}{l}1.80 \\
(.44)\end{array}$ & ns & $\begin{array}{l}-.58 \\
(-.50)\end{array}$ & ns & .92 & \\
\hline Control & $\begin{array}{l}.32 \\
(.97)\end{array}$ & $<.01$ & $\begin{array}{l}.60 \\
(.29)\end{array}$ & ns & $\begin{array}{l}-.18 \\
(-.31)\end{array}$ & ns & .92 & \\
\hline Less Reform & $\begin{array}{c}-.36 \\
(-1.41)\end{array}$ & $<.01$ & $\begin{array}{l}.92 \\
(.58)\end{array}$ & ns & $\begin{array}{c}.64 \\
(1.42)\end{array}$ & $<.01$ & .74 & 3.37 \\
\hline Control & $\begin{array}{c}.37 \\
(.70)\end{array}$ & ns & $\begin{array}{c}2.29 \\
(.69)\end{array}$ & ns & $\begin{array}{l}-.48 \\
(-.52)\end{array}$ & ns & .83 & \\
\hline
\end{tabular}

Sources: U.S. Bureau of the Census, City Government Finances (1945-1978); International City Management Association, Municipal Year Book (1945-1978) (Washington, D.C.); Commercial Atlas and Marketing Guide (1945-1978) (Chicago: Rand McNally).

*The $Q$ statistic may be compared with a $\chi^{2}$ distribution, where a value of 7.815 is necessary for statistical significance at the .05 level $(* *)$. Unless the $Q$ is significant, no autocorrelation is deemed to exist.

iations in slope or intercept appear for experimental cities, and one of these was in the wrong direction. Changing structure does not seem to matter much in allocating funds across different functional areas.

\section{Conclusion}

Disagreement persists over the potential policy consequences of urban political structures. Most of the prior attempts to investigate this linkage have dealt with the question of whether municipal reforms should induce cities to tax and spend more or less than unreformed cities. Despite Banfield and Wilson's widely known thesis suggesting that cities dominated by a middle-class publicregarding ethos may support greater public expenditures, a larger body of research tends to support the view that reformers wanted efficient, businesslike government with lower levels of spending. To complicate matters further, others have shown that reform characteristics have little or no impact on municipal spending levels. The research reported here, employing an interrupted time-series design for 22 cities over an 11-year period, generally confirms that changes in city government structure have almost no impact on changes in taxing and spending levels. We also discovered no consistent reallocation of expenditures among functional categories following changes in municipal structure.

This research represents the first attempt to analyze the effects of local government structure on policy using a genuine longitudinal design. If we accept the argument of Gray (1976) and others that theoretically policy making should be viewed as a process occurring over time, we believe our dynamic model is preferable to a cross-sectional analysis. Admittedly, this research is not likely to settle this dispute permanently-our findings are confined to fiscal variables, the time span is somewhat limited, and a relatively small number of cities are involved. Clearly something comparable to this analysis should be undertaken, where appropriate longitudinal data can be located, for other policy measures. Given these constraints, none of which we believe seriously limits what we have done, the findings are nonetheless unambiguous-urban reforms have few policy consequences.

What might we conclude about the efficacy of the reform movement based on these findings? There is a widely shared view that this group was largely successful in its effort to rid the cities of pernicious machine influences; presumably today's municipalities are more honestly governed, more efficient, and better managed than was true in the past. But the evidence offered here suggests these changes had little long-range effect on basic fiscal decisions. If the reformers wanted to keep the lid on city spending (which in itself is still arguable), they were not successful. No attempt is made here to minimize the overall import of the reform movement. Indeed, a number of community battles have been waged over the adoption of reform structures. Yet in the long run, government structure may matter very little-at least when it comes to city taxing and spending policies. 


\section{- References}

Banfield, Edward, and James Q. Wilson (1963). City Politics. New York: Vintage.

Boskoff, Alvin, and Harmon Zeigler (1964). Voting Patterns in a Local Election. Philadelphia: J.B. Lippincott.

Bowman, Lewis, Dennis S. Ippolito, and Martin L. Levin (1972). "Self-Interest and Referendum Support: The Case of a Rapid Transit Vote in Atlanta." In Harlan Hahn (ed.), People and Politics in Urban Society. Beverly Hills: Sage.

Box, George, and G. M. Jenkins (1970). Time Series Analysis, Forecasting and Control. San Francisco: Holden-Day.

Bryant, Stephen (1976). "The Dimensions of Reformism in Urban Policy Analysis." Urban Affairs Quarterly 12: 117-24.

Campbell, Donald T., and Julian C. Stanley (1966). Experimental and Quasi-Experimental Designs for Resarch. Chicago: Rand McNally.

Cole, Richard L. (1971). "The Urban Policy Process: A Note on Structural and Regional Influences." Social Science Quarterly 52: 646-55.

Commercial Atlas and Marketing Guide (1945-1978). Chicago: Rand McNally.

Durand, Roger (1972). "Ethnicity, 'Public-Regardingness,' and Referenda Voting." Midwest Journal of Political Science 16: 259-68.

Gray, Virginia (1976). "Models of Comparative State Politics: A Comparison of Cross-Sectional and Time Series Analysis." American Journal of Political Science 20: 235-56.

Hawkins, Brett (1971). Politics and Urban Policies. Indianapolis: Bobbs-Merrill.

Hays, Samuel P. (1964). "The Politics of Reform in Municipal Government in the Progressive Era." Pacific Northwest Quarterly 55: 157-69.

Hennessey, Timothy M. (1970). "Theory and Concept Formation in Comparative Urban Research." Midwest Journal of Political Science 14: 537-64.
International City Management Association (19451978). Municipal Year Book. Washington, D.C.

Judd, Dennis R. (1979). The Politics of American Cities. Boston: Little, Brown.

Leibert, Roland J. (1974). "Municipal Functions, Structures, and Expenditures: A Reanalysis of Recent Research." Social Science Quarterly 54: 765-83.

Lineberry, Robert L., and Edmund P. Fowler (1967). "Reformism and Public Policies in American Cities." American Political Science Review 61: 70116.

Lyons, William (1977). "Urban Structures and Policy: Reassessing Additive Assumptions of Reform." Political Methodology 4: 213-26.

(1978). "Reform and Response in American Cities: Structure and Policy Reconsidered." Social Science Quarterly 59: 118-32.

McCain, Leslie, and Richard McCleary (1979). "The Statistical Analysis of Interrupted Time-Series Quasi Experiments." In Thomas D. Cook and Donald T. Campbell (eds.), Quasi-Experimentation: Design and Analysis Issues for Field Settings. Chicago: Rand McNally.

Meier, Kenneth J. (1980). "Executive Reorganization of Government: Impact on Employment and Expenditures." American Journal of Political Science, 24: 396-412.

Miller, Abraham, and Stephen Bennett (1974). "Communication." American Political Science Review 68: 1265-71.

Ostrom, Charles W., Jr. (1978). Time Series Analysis: Regression Techniques. Beverly Hills: Sage Paper on Quantitative Applications in the Social Sciences.

Pack, David J. (1977). "Revealing Time Series Interrelationships." Decision Sciences 8: 377-402.

U.S. Bureau of the Census (1945-1978). City Government Finances. Washington, D.C.: Government Printing Office. 